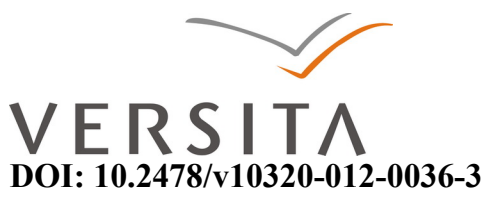

\title{
REPRESENTATIONS OF FEMININITY IN SEVENTEENTH CENTURY CONDUCT MANUALS FOR GENTLEMEN
}

\author{
STEFANIA BISCETTI \\ University of L'Aquila \\ Via Giovanni Falcone 25, 67100 Coppito (AQ), Italy \\ stefania.biscetti@cc.univaq.it
}

\begin{abstract}
This paper investigates conceptual representations of women in $17^{\text {th }}$ century conduct manuals for gentlemen published in England before and after the Civil War. The aim is to see whether the socio-cultural transformations produced by the Revolution are reflected in the metaphorical expressions referring to the female sex in a highly conservative textual genre
\end{abstract}

Keywords: conduct literature, femininity, gender roles, metaphor analysis

\section{Introduction}

This paper defines gender as a category of cognitive investigation. By "gender" historians and sociologists understand the "socially constructed meaning of sexual difference" (Crawford 1996:2), i.e. the social and cultural creation of ideas about the appropriate roles of men and women, their desirable qualities and power relations (Scott 1986; Eales 1998; Foyster 1999; Connell 1987, 2002).

Given the important role played by conduct literature in the construction of gender roles (Fletcher 1995), we are going to investigate the metaphorical coding of ideas of femininity (i.e. the cognitive representations of female gender) in $17^{\text {th }}$ century English conduct manuals addressed to men and their possible diachronic variation. The basic tenet here is that since metaphors reveal and construct human experience (Lakoff \& Johnson 1980; Kövecses 2005; Charteris-Black 2004), they are likely to reflect the 
profound transformations in culture and society such as those triggered in England by the Civil Wars (1641-1659).

\section{Seventeenth century England: an overview}

The beginning of the $17^{\text {th }}$ century is marked by political and religious tensions, culminating in the Civil Wars under Charles I (1625-1649). In this phase of English history religion and politics were so intertwined that the Bible was regarded not only as a moral and religious authority, but also "as a social and political blueprint" (Eales 1998:5). Justice and common law, for example, were meant to reflect God's will in terms of the wife's subordination to the husband.

The patriarchal system - with its assumptions about female insufficiency and inferiority - had scriptural justification in the story of Eve's creation - secondary and derived in nature. The separation of the spheres (whereby man was fit for the public and woman for the private) was another by-product of the alleged inferiority of women, and had both a biblical and a physiological (i.e. Galenic) explanation in women's physical, emotional and mental weakness. Thus, in the dichotomy mind/body advocated by $17^{\text {th }}$ century rationalist philosophers, reason was associated with maleness, and the body with the feminine (cf. Gouge's (1634:273) statement: "Though the man be as the head, yet is the woman as the heart").

The Civil War marked a turning-point in English history placed "between medieval and modern ways of thinking" (Hill 1969:198). The execution of Charles I in 1649 not only shook the foundations of the English political system, it also brought into question the patriarchal system.

Philosophical rationalism resulted in a critical approach to the Bible, no longer seen as an irrefutable authority on all subjects. One of the most remarkable phenomena of those years was the greater freedom enjoyed by women in public, political and religious activities. Radical women were allowed "to participate in church government, sometimes even to preach." (Hill 1975:310) They published (mostly on religious themes; see Crawford (1996: 93)), petitioned the Government on social and economic issues and participated in religious life as never before. With their conquest of the public sphere, women activists gained intellectual self-confidence, challenged the boundaries between 
male and female domains, and forced a revision of the gender codes. It must be said, however, that the questioning of many traditional ideas did not significantly alter old assumptions about the two sexes (Crawford 1996:9). Legal evidence of the endurance of a double sexual standard, for example, was an act passed in 1650 which defined adultery as a crime that could only be committed by women (Foyster 1999:78).

Although the transformations produced by the Revolution were in theory reversed with the return of Charles II, "1660 did not - could not - restore 1640" (Hill 1990:21). Tolerance (to be intended more as permissiveness rather than as religious toleration) became a feature of the Restoration period. This could be seen, for example, in the reopening of public theatres and in the regular appearance of women on the stage, as well as in the concern for bad form rather than sin characterizing Restoration comedy.

As for the upsetting of gender relations and the questioning of traditional hierarchy during the Revolution, using evidence from conduct literature, Fissell (1995:442) claims that while pre-war writers were more concerned with male chastity and female submission within marriage, post-war authors emphasize the dangers of female unruly sexual behaviour, no longer aggressive but potentially disruptive of social order. Restricting women's access to the public sphere was men's response to the female sexual threat. Shoemaker (1998:33) makes the point that this increased separation of the spheres is reflected in conduct literature by a shift in focus from women's vices and weaknesses (especially lust) to their natural inclination to virtue.

Evidence of continuity (rather than crisis) in gender relations has instead been found in that the view of woman as emotional, fragile and easily led astray not only remained unaltered after 1660, but "was confirmed by the experiences of the revolutionary years" (Crawford 1996:185). Foyster's (1999:210) conclusion about the endurance of patriarchal ideology throughout the seventeenth century goes in the same direction.

Keeping in mind the fact that changes in the political, economic and social macrostructure are slow to penetrate the language and thought of a community and to emerge as metaphors in discourse, the above claims about continuity and change in the ways of representing women will be put to the test of metaphor analysis. 


\section{Sources}

The sources considered here belong to the Puritan tradition of conduct literature chiefly concerned with the education of young gentlemen and focused on moral issues such as honour and virtue. Pre-war material consists of Heropaideia, or The Institution of a Young Noble Man (1607) by James Cleland, The Compleat Gentleman (1622) by Henry Peacham, and The English Gentleman (1630) by Richard Brathwaite. Post-war material includes The Gentleman's Calling (1660) by Richard Allestree, The Gentleman's Companion (1672) by William Ramesey, and Advice to a Young Lord (1691) by Thomas Fairfax. Although “a condensation with slight revisions" (Sloane 1940:417-418) of Archibald Campbell's Instructions to a Son (1661), Fairfax's manual can be credited a late $16^{\text {th }}$ century exemplar of conduct literature, if borrowing from an older work is taken to imply that certain ideas were still topical thirty years later.

Feminine metaphors, extracted manually, form a corpus of 39 tokens, of which 7 from pre-war sources and 32 from post-war sources.

\section{Metaphors in pre-war sources}

Female metaphors only amount to 7 types and tokens, distributed unevenly among the three manuals: 2 in Cleland (WOMAN IS A MAGNET (1), WOMAN IS AN ENSNARER/HUNTER (2)) and 5 in Brathwaite (WOMAN IS A VIPER \& A WARRIOR (3), WOMAN IS A PRIZE (4), WOMAN IS A COMMODITY (5), WOMAN IS A BEAST (6), BEAUTY IS AN ENSLAVER (i.e. A BEAUTIFUL WOMAN IS AN ENSLAVER) (7)).

1) ... I wish you alwaies [...] that you bee ever upon your guarde, chieflie amongst those who are faire, of a comlie, gracious, and alluring behaviour. (Cleland p. 245)

2) Abstaine frõ the company of these impudent Laïs, who with their painted faces, smooth tongues, \& glancing eyes study to entrap young Gentlemen in their snares; (Cleland p. 245 a)

3) my exhortation is to Youth, [...] that you shake off these vipers [i.e. women with an harlot's behaviour] at the first assault, and prevent the occasion when it first offers it selfe. (Brathwaite, p. 24)

4) But you will object; to vanquish where there is no assault made, is a weak conquest; (Brathwaite p. 33)

5) as I would not have you to entertaine so maine a businesse [i.e. choosing a wife] without mature advice, so I would not have you wholly rely upon a friends counsell; as you are to have the 
greatest Ore in the Boat, so to make your selfe your owne carver: for he that is enforced to his Choice, makes a dangerous bargaine. (Brathwaite p. 262)

6) Idlenesse maketh of men, women, of women, beasts, of beasts, monsters. (Brathwaite pp. $32 ; 124)$

7) To court Beautie is an enterprize of danger: for some I have knowne, who upon their accesse to Beautie, have beene free-men, who upon their returne, became slaves. (Brathwaite p. 33)

Albeit scarce in number, they give us a clear idea of how woman is seen in relation to man. Woman is here represented as powerful (i.e. as dangerous for their power of attraction (1) and control (7), as aggressive (3) and deceiving (2)) and powerless (i.e. as the object of male conquest (4), as man's property (5) and as an inferior being (6)), with a negative connotation in both cases. The picture of the early seventeenth century English woman emerging from these metaphors is that of a creature engaged in seduction and sexual conquest. Unlike male power, female powerfulness is negatively valued because of its association with sexuality and vice/sin. The powerful woman is the lustful, tempting virago ((2), (3)), who threatens a man's honour and freedom with speech, lascivious behaviour and beauty, her most powerful weapon of conquest (7). Uncontrolled lust was commonly considered a sign of women's weakness of mind and will, and of their being closer than man to nature and brute beasts (6). (see Thomas $1983: 41)$

These data seem to confirm the emphasis of pre-war conduct literature on female aggressive sexual behaviour (Fissell 1995:442) and on women's lust (Shoemaker 1998:33). There is instead no reference to women's subjection within marriage (Fissell 1995:442), while reference to women's emotional unsteadiness and frailty (Crawford 1996:185) can only be gathered from their voracious sexuality, which they are unable to control. Here woman is not only subordinate and inferior to man in the divine hierarchy (i.e. outside marriage) (6); she is utterly reified as a man's possession (5).

\section{Metaphors in post-war sources}

The post-war manuals I analysed contain 32 female metaphors distributed as follows: 2 in Allestree (WOMAN IS A WARRIOR (8), WOMEN ARE GAME/PREYS (9)): 
8) Sometimes [...] Lust attaques him [i.e. man] with the piercing darts, the killing glances of a prostitute Beauty. (p. 71)

9) So if they hear but of a beautiful Woman, what contrivancies, what designs do they lay, first to see, and then to corrupt her; make it a business to themselves, [...], to spring such game? (p. 109)

18 in Ramesey (WOMAN IS A FORTRESS (10), WOMAN IS A MASTERPIECE (11), WOMAN IS MAN'S GLORY (11), WOMAN IS A SUBJECT (12) and (13), WOMAN IS A PLAGUE (14), WOMAN IS A CABINET (15), WOMAN IS AN OBJECT (16), WOMAN IS AN INFERIOR BEING (17), WOMAN IS A CONTROLLER (18), WOMAN IS A BRIGHT_ENTITY (19), WOMAN IS AN ENSNARER (19), WOMAN IS AN EXCREMENT (22); BEAUTY IS A TENDER FLOWER, A TEMPTATION, A SNARE and A FOLLy (20), BEAUTY IS A FLASH and A VENICE GLASS (21)):

10) [...] 'tis great folly in Parents $[\ldots]$ if they have not [...] as much care in the Education of their Daughters, as Sons; especially in this Age, wherein they need to be furnisht with abundance of Virtue, to withstand the continuous assaults Men make on their Chastity. (p. 13)

11) $[\ldots]$ and then lastly, [God] ends with the Creation of the Woman, as the Masterpiece of Nature, and glory of the Man. (pp. 10-11)

12) [...] were not we taught by an infallible Spirit, that the Man is the Head of the Woman; and that he was not made for her, but she for him, and he for God; and therefore is she to be in subjection to the Man. (p. 11)

13) But when thy choice is made, thou must treat her [the wife] with all Love and Civility (yet so as that thy Love do not enervate thy Rule over her, nor that lessen thy Love) (p. 94)

14) To have a Scold, a Fool, a Whore, a Fury, is the worst of Plagues, and an Hell upon Earth. (p. 91)

15) [...] if a Man have a Cabinet that every mans Key will open as well as his own, why should he think to keep it private? (p. 96)

16) .. many narrow-witted People [...] may [...] conclude the use of Women sinful, because some have been clapt by them. (pp. 125-126)

17) Nay, 'tis [i.e. anger] a kind of baseness, and pusillanimity, and so, beneath a Gentleman. For wee see such as are weak, sickly, Aged, or else Children, Fools, and Women most addicted to it. (p. 186)

18) A Batchelor lives free, $[\ldots]$ He has $[\ldots]$ none to please, nor none to displease, and controul him; (p. 199) 
19) Let not the Splendour of her Beauty [...] or Gold dazzle the eyes of thy understanding, and obfuscate thy judgment as to precipitate thee into such a Pitfall. (pp. 92-93)

20) [...] the Splendour of her Beauty (which is so tender a Flower, that the blast of any Sickness shrivels to nothing, A Temptation, if not, oft-times, a snare to thy self, and others; the greatest folly imaginable) (pp. 92-93)

21) Every day detracts form her Person. Beauty is but a mere flash, a Venice Glass, quickly broken by any Disease. (p. 197)

22) After she has been Married a while, has had two or three Children, she will be so altered, her nearest Relations will hardly know her. But, at best, bethink thy self, 'tis but Earth thou lovest. A mere excrement (as some will) that vexeth thee. (pp. 197-198)

12 in Fairfax (WOMAN IS A DANGER (23) and (24), WOMAN IS AN EMPRESS (25), WOMAN IS A MAGNET (26), WOMAN IS A HELPER (27) and (33); BEAUTY AND WEALTH ARE BRIGHT ENTITIES (28), BEAUTY IS A DECEIT (28), BEAUTY IS WITCHERY (29), BEAUTY IS A CONQUEROR (30), BEAUTY IS CLAY (31), BEAUTY IS A WEAK AND GAY ARMY (32)):

23) The Converse of ill Women is altogether to be shunned, lest you be fascinated by their Beauty and Subtleties, to the ruine of your Welfare hereafter, as well as your Estate here. (p. 102)

24) Several Men esteem it no little Felicity to enjoy the Company of fine Women, but they consider not to what Dangers they oblige themselves, ... (p.102)

25) ... for nothing is so chargeable [with the ruin of a man's fortunes] as an imperious Beauty. (p. 103)

26) [...] keep your mind fast shut against their [i.e. women's] Charms and Allurements. (p. 103)

27) 'Tis one of the chiefest ends of the Almighty's Creation of Women that they might be an help meet (that is necessary) for Men; (p. 43)

28) [...] Wealth and Beauty; the latter of which especially I would not have you over-blinded with, 'tis one of the greatest deceits Nature is guilty of; (p. 47)

29) [beauty is a deceit] in the fascination and witchery it darts through the Eyes into the Minds of Men; (p. 47)

30) you cannot but pay homage to it [i.e. female beauty], but let that Tribute redeem you from a Total Conquest. (pp. 47-48)

31) Remember therefore that it [female beauty] is but Clay more refined, and set off with a better varnish, and being all on the out-side, lies more open and obnoxious to weather, and consuming time, and very often to present misfortunes; (p. 48) 
32) [...] the other [outer beauty] [...] is but a weak and gay Army, ready to be vanquish'd at the first Onset, and Encounter. (pp. 48-49)

33) [...] God did oftentimes reward the good works, the Honesty and piety of a Man, with the tender of a good and discreet Wife; (p. 45)

As before, type frequency almost equals token frequency. The greater number and variety of types (here female metaphors are almost four times as much as in pre-war manuals), however, suggest that woman has gained relevance in post-war sources, and that post-war authors are more concerned than before with defining manhood in relation to women both within and outside marriage. As a matter of fact, unlike before reference is here made to woman's subjection ((12), (13), (27), (33)), unruly sexual behaviour ((14), (15)) and power ((14), (18)) in marriage.

As in pre-war manuals, woman is represented as powerful (e.g., as sexually aggressive (8), controlling (18), dangerous (24), overbearing (25), attracting (26)) and powerless (e.g., as the target of male conquest (9), as a sexual object (16), as emotionally weak (17) and instrumental to man (11), (27) and (33)), with a constant negative evaluation. Three metaphors standing out for their positive connotation are instead WOMAN IS A FORTRESS (10), WOMAN IS A MASTERPIECE (11) and the semi-positive (because of woman's instrumental role) WOMAN IS MAN'S GLORY (11), all from Ramesey. These metaphors reflect the author's positive attitude to women, considered "no less Rational, Intelectual, and Docible, than Men" (p.9) and "for the most part, more pitiful, more pious, faithful, merciful, chaste, beautiful, than Men" (p. 10).

Yet, in spite of such emphasis on women's equality or superiority to men in virtues, women are seen as emotionally fragile (i.e. as naturally inclined to passions) (17) and lustful (34), just as in Allestree (8) and Fairfax (35), where no word is spent in praise of the female sex:

34) $[. .$.$] thou wilt not be so fond if you observest her faults. Especially those of the Mind; her$ Pride, Envy, Incontinency, Weakness, Lightness, Self-wit, Jealousie, Insatiable Lust, \&c. (Ramesey, p. 198)

35) A Great Philosopher tells us, A Man ought to approach his Wife in fear, lest too wantonly provoking her desires, the pleasure thereof make her exceed the bounds of reason. (Fairfax, p. 55) 
Allestree's metaphorization of lust (8) as "the killing glances of a prostitute Beauty" establishes a complex association between sexual aggressiveness, immorality and female beauty which also appears in Fairfax (23), although simplified (i.e. without the aggressive component). In Fairfax the power and dangers of female beauty are so prominent ((23)-(26); (28)-(30)) and set on a par with those of lust, that beauty actually becomes a cognitive-semantic substitute for lust. In arousing male lust, female beauty makes men irrational (in Fairfax) ((19), (28)), and women victims of their own power of attraction (in Allestree) (9).

Not all metaphors equate female beauty with power, though. In (20), (21), (31) and (32) beauty is the emblem of frailty (glass and clay), perishableness (flower) and weakness (weak army). Strength belongs to inward beauty (i.e. virtues), which solely should guide a man in choosing a wife.

The two opposite but equally negative conceptualizations of beauty as power and fragility still reflect early $17^{\text {th }}$ century attitudes towards the flesh, either demonized or mortified as the negative pole of the pair body-mind. The subordination of the body (identified with the feminine) to the mind (associated to the masculine) is visible in (12), (13) and (27), where woman is subject to man both within marriage ((13) and (27)) and outside it (12).

\section{Conclusions}

The aim of this paper was to uncover possible variation in men's perspective on women reflecting the profound social and political changes produced during the revolutionary years through the analysis of feminine metaphors present in $17^{\text {th }}$ century courtesy books for gentlemen published in England before and after the Civil War. A corpus of 39 feminine metaphors extracted manually from three pre-war and three postwar male conduct books was used as testing ground for a number of claims on the representation of women in $17^{\text {th }}$ century conduct literature for women. Given the nature of the sources used, our findings were expected to diverge substantially from those of previous studies based on the prescriptive discourse on female conduct, where woman is especially represented as an ideal model of behaviour according to a male perspective. 
Instead of representing how women should be, our data represent in fact how women are perceived or are to be seen by men obsessed as they were with reputation and selfcontrol. The results of our analysis can be summarized as follows:

In pre-war sources woman is mainly seen as sexually aggressive and lustful, hence as a dangerous threat to male honour, understood as virtue, esteem and selfmastery (Biscetti, in preparation; Fletcher 1995:126).

In post-war data sexual aggressiveness is only marginally present (with only one occurrence out of 32 metaphors), whereas female lust remains a female prerogative and a correlate of beauty. In fact, in post-war sources female beauty is utterly identified with lust and becomes a semantic-cognitive substitute for it (i.e. beauty implies lust). Instead of emphasizing "the dangers of female unruly sexual behaviour" (Fissell 1995:442), our post-war authors emphasize the dangers of female beauty for men's welfare in marriage, as beauty can obfuscate a man's judgement and make him blind to her vices. The fact that beauty is here a threat to a man's happiness rather than to his virtue (as in pre-war sources) is a clear sign of the secularization of the times.

As to women's subjection to men within marriage, contrary to Fissell's (1995: 442) finding, no reference has been found to this in pre-war data.

In spite of a sense of female superiority emerging from a few metaphors in postwar data, the negative view of women as powerful and dangerous is too persistent and statistically relevant for those positively connoted metaphors to be taken as evidence of a shift in focus from women's vices to virtues observed by Shoemaker (1998:33) in conduct manuals for women. The picture we get from our data seems closer to Foyster's (1999:210) claim about the endurance of patriarchal ideology throughout the century and to Crawford's (1996:9) view that old assumptions about the female sex remained more or less unaltered after the Revolution.

\section{References}

Allestree, R. 1660. The Gentleman's Calling. London: Printed for T. Garthwait.

Biscetti, S. (in preparation) 'Representations of Masculinity in Seventeenth-Century

Courtesy Books.'

Brathwaite, R. 1630. The English Gentleman. London: Printed by John Haviland.

Campbell, A. 1661. Instructions to a Son. Printed at Edinborough, and Reprinted at 
London for D. Trench.

Charteris-Black, J. 2004. Corpus Approaches to Critical Metaphor Analysis.

Basingstoke and New York: Palgrave Macmillan.

Cleland, J. 1607. Heropaideia, or The Institution of a Young Noble Man. Oxford:

Printed by Ioseph Barnes.

Connell, R. 1987. Gender and Power: Society, the Person and Sexual Politics.

Cambridge: Polity Press.

Connell, R. 2002. Gender. Cambridge: Polity Press.

Crawford, P. 1996 (1993). Women and Religion in England 1500-1720. London and

New York: Routledge.

Eales, J. 1998. Women in Early Modern England, 1500-1700. London and Bristol: UCL Press.

Fairfax, T. 1691. Advice to a Young Lord, Written by his Father. London: Printed for R. Baldwin.

Fissell, M. 1995. 'Gender and Generation: Representing Reproduction in Early Modern England' in Gender \& History, 7/3, pp.433-456.

Fletcher, A. 1995. Gender, Sex and Subordination in England 1500-1800. New Haven and London: Yale University Press.

Foyster, E. A. 1999. Manhood in Early Modern England: Honour, Sex and Marriage. London and New York: Longman.

Gouge, W. 1634. Of Domesticall Duties. London: Printed by George Miller for Edward Brewster.

Hill, C. 1969. The Pelican Economic History of Britain: Reformation to Industrial Revolution 1530-1780. Harmondsworth: Penguin.

Hill, C. 1975 (1972). The World Turned Upside Down: Radical Ideas During the English Revolution. Harmondsworth: Penguin.

Hill, C. 1990. A Nation of Change and Novelty: Radical Politics, Religion and Literature in Seventeenth-Century England. London: Routledge.

Kövecses, Z. 2005. Metaphor in Culture: Universality and Variation. New York: Cambridge University Press.

Lakoff, G. and Johnson, M. 1980. Metaphors We Live By. Chicago and London: The University of Chicago Press.

Peacham, H. 1622. The Compleat Gentleman. London: Imprinted for Francis Constable.

Ramesey, W. 1672. The Gentleman's Companion: Or, a Character of True Nobility and Gentility. London: Printed by E. Ok[es] for Rowland Reynolds.

Scott, J. 1986. 'Gender: A Useful Category of Historical Analysis' in American Historical Review. 91/5, pp.1053-1075. 
Shoemaker, R. B. 1998. Gender in English Society, 1650-1850: The Emergence of Separate Spheres? London and New York: Longman.

Sloane, W. 1940. 'Some Plagiarisms in $17^{\text {th }}$ Century Books of Advice to Children' in Modern Language Notes 55/6, pp.416-418.

Thomas, K.V. 1983. Man and the Natural World: Changing Attitudes in England, 15001800. London: Allen Lane. 